\title{
Polyol Synthesis of Ruthenium Selenide Catalysts for Oxygen Reduction Reaction ${ }^{\dagger}$
}

\author{
Ki Rak Lee and Seong Ihl Woo*
}

\author{
Department of Chemical and Biomolecular Engineering (BK21 Graduate Program), \\ Korea Advanced Institute of Science and Technology, Daejeon 305-701, Korea. E-mail: siwoo@kaist.ac.kr \\ Received July 14, 2010, Accepted September 30, 2010
}

\begin{abstract}
Ruthenium catalysts modified by selenium have been introduced as alternative materials to Pt in Direct methanol fuel cells (DMFCs). RuSe nano-particles were synthesized on the Vulcan XC72R carbon supports via polyol method. The prepared catalysts were electrochemically and physically characterized by cyclic voltammetry $(\mathrm{CV}$,$) linear sweep$ voltammetry, methanol tolerance test, X-ray diffraction (XRD), Transmission electron microscopy (TEM), Energydispersive Spectrometer (EDS) and X-ray photoelectron spectroscopy (XPS). Increasing the Se concentration up to 20 at \% increased the electro-catalytic activity for the oxygen reduction. By increasing Se amount, Ru metallic form on the surface was increased. The $\mathrm{Ru}_{80} \mathrm{Se}_{20} / \mathrm{C}$ catalysts showed the highest oxygen reduction reaction (ORR) activity and outstanding methanol tolerant property in half cell tests as well as single cell test.
\end{abstract}

Key Words: Ruthenium-chalcogenide, Fuel cell, Oxygen reduction reaction, Electro-catalysts, Methanol tolerant property

\section{Introduction}

DMFCs are becoming promising power sources to substitute fuel combustion energies as well as batteries in portable electronic devices. ${ }^{1-5}$ Significant and intensive investigations in this field have been progressed to commercialize this device. Until now, all low-temperature fuel cells including DMFCs have used platinum or platinum based materials as the electrode. PtRu alloy catalysts are widely used as the anode material. ${ }^{6,7}$ In the cathode, platinum shows an outstanding performance for oxygen reduction such as the highest catalytic activity and stability. Its high cost, however, is a serious problem. This problem has to be solved for successful commercialization. To solve the economic problem, Pt-transition metal alloy materials such as $\mathrm{PtNi},{ }^{8,9} \mathrm{PtCo},{ }^{10,11}$ and $\mathrm{PtCr}^{12}$ are developed as ORR catalysts. Furthermore, ternary or quaternary Pt based catalysts ${ }^{13,14}$ and $\mathrm{Pt}$ nano-particles with new support materials ${ }^{15-17}$ are introduced. These materials show the improved ORR activity because prevention of the particle sintering, surface roughening from the removal of some alloy metal, proper crystallographic geometry, and change of Pt-Pt inter-atomic distance causing change of Pt electro binding energy. ${ }^{18,19}$ Amounts of platinum, however, are still needed and it is not enough. Furthermore, platinum based catalysts show low methanol tolerance property. It is not suitable for the cathode material in DMFCs. Amount of methanol crossover generally occurs from the anode to cathode in DMFCs. Methanol crossover is the main reason for the drop in performance in the cathode. ${ }^{20,21}$ Development of economic catalysts with high ORR activity and methanol tolerant property is needed.

Recently, many researchers have interested in the development of Pt-free materials for oxygen electro-reduction. Efforts have been made to develop the non-platinum ORR catalysts such as Pd alloy matertials, ${ }^{22-24}$ transition-metal macrocyclic compounds, ${ }^{25,26} \mathrm{Ru}$ based materials, ${ }^{14,27,28}$ and $\mathrm{N}$ doped carbon

\footnotetext{
${ }^{\top}$ This paper is dedicated to Professor Hasuck Kim for his outstanding contribution to electrochemistry and analytical chemistry.
}

materials. ${ }^{29-31}$ The approach of non-Pt catalysts not only makes fuel cells economical but also clears methanol crossover problem. Among various non-Pt catalysts, Ru based catalysts show good catalytic activity in ORR and high selectivity for fourelectron reduction of oxygen to water in acidic media. The $\mathrm{Ru}$ based chalcogenides can be divided into Chevrel phases ${ }^{32}$ and amorphous ruthenium chalcogenides. ${ }^{33}$ The former shows good performance as a cathode material. They are generally prepared by solid-state reaction in high temperature and pressure which is very complicated and expensive. The latter shows efficient activity for ORR in acidic media at low temperatures.

In this study, the Ru-chalcogenide (RuSe) nano-particles were synthesized on the carbon support via polyol method and an optimum composition was found. Polyol reduction is a well known process for synthesizing metallic nanoparticles. ${ }^{34}$ For comparison, $\mathrm{Ru} / \mathrm{C}$ was prepared with the same process. The prepared $\mathrm{RuSe} / \mathrm{C}$ catalysts were tested for electro-chemical studies in half-cells as well as in single cells, and physical characterizations were carried out by XRD and XPS.

\section{Experimental}

RuSe nano particles were deposited on Vulcan XC72R using ethylene glycol as a reducing agent via polyol process. ${ }^{35}$ Ruthenium acetylacetonate and selenium tetrachloride were dissolved in ethylene glycol and then Vulcan XC72R was added to the solution. The suspension was sonicated and stirred for $1 \mathrm{~h}$ under $\mathrm{N}_{2}$ condition. The suspension was then refluxed at $160{ }^{\circ} \mathrm{C}$ under $\mathrm{N}_{2}$ condition with continuous stirring for $4 \mathrm{~h}$. After the reflux, the suspension was filtered and washed with DI water and ethanol. Finally, the catalysts were dried at $80{ }^{\circ} \mathrm{C}$, overnight. The prepared catalysts are notated as $\mathrm{Ru} / \mathrm{C}, \mathrm{Ru}_{95} \mathrm{Se}_{5} / \mathrm{C}, \mathrm{Ru}_{90} \mathrm{Se}_{10} / \mathrm{C}$, $\mathrm{Ru}_{85} \mathrm{Se}_{15} / \mathrm{C}, \mathrm{Ru}_{80} \mathrm{Se}_{20} / \mathrm{C}$, and $\mathrm{Ru}_{75} \mathrm{Se}_{25} / \mathrm{C}$ to their atomic composition ratios. The $\mathrm{Ru}_{\mathrm{x}} \mathrm{Se}_{100-\mathrm{x}} / \mathrm{C}$ notation means a prepared ratio. Loading of metals was $60 \mathrm{wt} \%$. All chemicals were analytical grade or better and were purchased from Sigma-Aldrich. 
$\mathrm{XRD}$ analysis was performed using a $\mathrm{Cu} \mathrm{K} \alpha$ radiation with a D/MAX-IIIC diffractometer for characterization of structural properties of the powder catalysts. XPS measurements were performed using $\mathrm{Al} \mathrm{K} \alpha$ radiation and the constant pass energy of $25 \mathrm{eV}$. The XPS peak software version 4.1 was used, and spectral peaks were fitted using a mixed Gaussian-Lorentzian (80:20) line and Shirley baselines. TEM analysis was done on a field emission transmission electron microscope (Tecnai $\mathrm{G}^{2}$ F30 S-Twin). EDS analysis was carried out using a field emission SEM (Nova230) at an acceleration voltage of $20 \mathrm{kV}$.

Electrochemical analysis was carried out in a three electrode cell with a platinum counter electrode, an $\mathrm{Ag} / \mathrm{AgCl}$ reference electrode (BAS Co., Ltd., MF-2052 RE5B), and a glassy carbon working electrode (3 mm dia, BAS Co., Ltd., MF-2012). The working electrodes were prepared by the thin-film electrode method $^{36}$ and had a loading of $80 \mu \mathrm{g}$ catalyst. The prepared electrodes were tested for CV and linear sweep voltammetry tests. The $\mathrm{CV}$ test was performed between 0.0 and $0.8 \mathrm{~V}$ ( $v s$. reference hydrogen electrode (RHE)) at a scan rate of $15 \mathrm{mV} \mathrm{s}^{-1}$. Nitrogen purged $1 \mathrm{M} \mathrm{HClO}_{4}$ solution was used as an electrolyte. The linear sweep voltammetry was performed by rotating the working electrodes at a scan rate of $5 \mathrm{mV} \mathrm{s}^{-1}$ in oxygen saturated $1 \mathrm{M} \mathrm{HClO}_{4}$ solution and in oxygen saturated $1 \mathrm{MHClO}_{4}+0.1 \mathrm{M}$ methanol solution, respectively. All electrochemical experiments were carried out at room temperature and at ambient pressure. All potentials in this study were converted to RHE scale.

The membrane electrode assemblies (MEAs) were fabricated by spraying the catalyst onto Nafion 112 , The anode catalyst was $\mathrm{PtRu} / \mathrm{C}(\mathrm{E}-\mathrm{tek}, 60 \mathrm{wt} \%, \mathrm{Pt}: \mathrm{Ru}=1: 1$ atomic ratio) and the cathode catalyst was $\mathrm{Pt} / \mathrm{C}$ (E-tek, $60 \mathrm{wt} \%$ ) and $\mathrm{Ru}_{80} \mathrm{Se}_{20} / \mathrm{C}$. The catalyst loading was $2.5 \mathrm{mg} \mathrm{cm}{ }^{-2}$. The catalyst-coated membranes were hot-pressed at $120^{\circ} \mathrm{C}$ for $3 \mathrm{~min}$. Polarization curves were obtained using a homemade single cell with an active area of $4 \mathrm{~cm}^{2} .1 \mathrm{M}$ methanol and oxygen were fed into the anode and cathode at the flow rate of $1 \mathrm{~mL} \mathrm{~min}^{-1}$ and $100 \mathrm{cc} \mathrm{min}^{-1}$, respectively. The single cells were operated at $70{ }^{\circ} \mathrm{C}$.

\section{Results and Discussions}

Fig. 1(a) shows a TEM image of the $\mathrm{Ru}_{80} \mathrm{Se}_{20} / \mathrm{C}$ catalyst. There are nano sized metal particles on the carbon support. However, a non-homogeneous particle distribution is observed due to the high RuSe loading. Reliable analysis of the particle size is difficult from TEM image. The particle size of each catalysts was calculated from XRD analysis. XRD results of the synthesized catalysts are shown in Fig. 1(b). The broad peak at $2 \theta$ value of $25^{\circ}$ was related to (002) plane of the hexagonal structure of Vulcan XC-72R carbon support. ${ }^{37}$ Selenium or selenide phase was not detected in XRD results. It is the reason that the selenium is present in the form of a fully amorphous phase or the amount of crystalline selenium is below the XRD sensitivity. ${ }^{38}$ The (110) diffraction peak of crystallographic $\mathrm{Ru}$ plane was used for analysis of the structural properties. The (110) peaks were observed at $2 \theta$ values of $69.40^{\circ}$ for $\mathrm{Ru} / \mathrm{C}, 69.40^{\circ}$ for $\mathrm{Ru}_{95} \mathrm{Se}_{5} / \mathrm{C}, 69.42^{\circ}$ for $\mathrm{Ru}_{90} \mathrm{Se}_{10} / \mathrm{C}, 69.45^{\circ}$ for $\mathrm{Ru}_{85} \mathrm{Se}_{15} / \mathrm{C}, 69.50^{\circ}$ for $\mathrm{Ru}_{80} \mathrm{Se}_{20} / \mathrm{C}$, and $69.50^{\circ}$ for $\mathrm{Ru}_{75} \mathrm{Se}_{25} / \mathrm{C}$, respectively. The (110) peaks of the synthesized catalysts appe- (a)

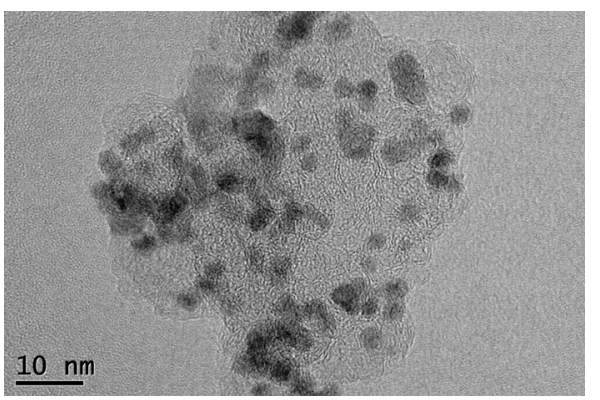

(b)

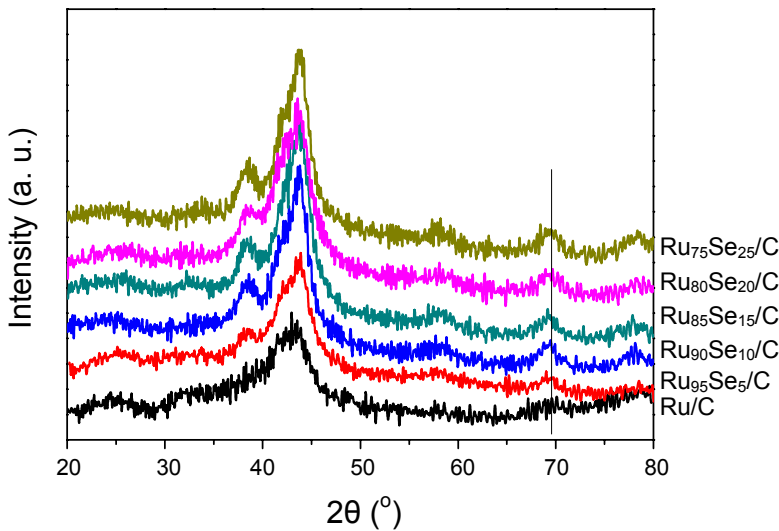

Figure 1. TEM image of the $\mathrm{Ru}_{80} \mathrm{Se}_{20} / \mathrm{C}$ catalyst (a) and XRD results of the $\mathrm{Ru} / \mathrm{C}, \mathrm{Ru}_{95} \mathrm{Se}_{5} / \mathrm{C}, \mathrm{Ru}_{90} \mathrm{Se}_{10} / \mathrm{C}, \mathrm{Ru}_{85} \mathrm{Se}_{15} / \mathrm{C}, \mathrm{Ru}_{80} \mathrm{Se}_{20} / \mathrm{C}$, and $\mathrm{Ru}_{75} \mathrm{Se}_{25} / \mathrm{C}$ catalysts (b).

ared at similar $2 \theta$ values, indicating the low degree of alloy in most catalysts. The average particle sizes were calculated using the Debye-Scherrer equation. ${ }^{39}$ Average particle sized were 4.9, 5.1, 3.9, 3.6, 4.1, and $4.6 \mathrm{~nm}$ for the $\mathrm{Ru} / \mathrm{C}, \mathrm{Ru}_{95} \mathrm{Se}_{5} / \mathrm{C}$, $\mathrm{Ru}_{90} \mathrm{Se}_{10} / \mathrm{C}, \mathrm{Ru}_{85} \mathrm{Se}_{15} / \mathrm{C}, \mathrm{Ru}_{80} \mathrm{Se}_{20} / \mathrm{C}$, and $\mathrm{Ru}_{75} \mathrm{Se}_{25} / \mathrm{C}$, respectively. The EDS data showed the purposed bulk compositions of $\mathrm{Ru}$ and Se on each catalyst. However, selenium was not detected from XRD analysis. It means that the Se forms an amorphous phase on the RuSe catalysts. A summary of the XRD and EDS results are listed in Table 1.

Electrochemical analysis of the synthesized catalysts is shown in Fig. 2. Fig. 2(a) shows $\mathrm{CV}$ results of the $\mathrm{Ru} / \mathrm{C}$ and $\mathrm{Ru}_{100-\mathrm{x}} \mathrm{Se}_{\mathrm{x}} / \mathrm{C}$ catalysts. With $\mathrm{Ru} / \mathrm{C}$ catalyst in the range $0-0.2 \mathrm{~V}$, an anodic peak was attributed to hydrogen desorption from $\mathrm{Ru}$ surface. ${ }^{40,41}$ In the region $0.2-0.8 \mathrm{~V}$, an increasing anodic current was detected due to the ruthenium surface oxidation and adsorption of water related species, such as the hydroxyl group. ${ }^{42,43}$ The cathodic peak around $0.2 \mathrm{~V}$ was caused by reduction of oxidized Ru surface and adsorption of hydrogen on $\mathrm{Ru}$ surface. ${ }^{44-46}$ Increasing Se amount in the catalysts, however, the hydrogen adsorption peak is significantly suppressed, indicating that Ru surface was modified by Se. Furthermore, increasing Se amount, Ru oxidation peaks were significantly suppressed. It was reported that Se stabilized Ru surface against oxidation. ${ }^{47}$ Following the $\mathrm{CV}$ studies, we conducted ORR measurements (Fig. 2(b)). For a comparison, Pt/C (E-tek, $60 \mathrm{wt} \mathrm{\% )} \mathrm{is} \mathrm{also}$ measured. Current densities at $0.7 \mathrm{~V}$ were $-1.26,-1.47,-1.55$, $-1.74,-1.87,-0.95$ and $-2.23 \mathrm{~mA} \mathrm{~cm}{ }^{-2}$ for the $\mathrm{Ru} / \mathrm{C}, \mathrm{Ru}_{95} \mathrm{Se}_{5} / \mathrm{C}$, $\mathrm{Ru}_{90} \mathrm{Se}_{10} / \mathrm{C}, \mathrm{Ru}_{85} \mathrm{Se}_{15} / \mathrm{C}, \mathrm{Ru}_{80} \mathrm{Se}_{20} / \mathrm{C}, \mathrm{Ru}_{75} \mathrm{Se}_{25} / \mathrm{C}$, and Pt/C. In the $\mathrm{Ru}$ based catalysts, the $\mathrm{Ru}_{80} \mathrm{Se}_{20} / \mathrm{C}$ catalyst showed the high- 
Table 1. Summary of physical and electrochemical properties of the $\mathrm{Ru} / \mathrm{C}, \mathrm{Ru}_{95} \mathrm{Se} \mathrm{Se}_{5} / \mathrm{C}, \mathrm{Ru}_{90} \mathrm{Se}_{10} / \mathrm{C}, \mathrm{Ru}_{85} \mathrm{Se}_{15} / \mathrm{C}, \mathrm{Ru}_{80} \mathrm{Se}_{20} / \mathrm{C}, \mathrm{and} \mathrm{Ru}_{75} \mathrm{Se}_{25} / \mathrm{C}$ catalysts

\begin{tabular}{|c|c|c|c|c|c|c|c|c|c|}
\hline & \multicolumn{7}{|c|}{ Physical characterization } & \multirow{2}{*}{\multicolumn{2}{|c|}{$\frac{\text { Electrochemical characterization }}{\text { ORR }}$}} \\
\hline & \multicolumn{2}{|c|}{ XRD } & \multirow{2}{*}{$\begin{array}{c}\text { EDS } \\
\begin{array}{c}\mathrm{Ru}: \mathrm{Se} \\
(\text { atom \%) }\end{array}\end{array}$} & \multicolumn{4}{|c|}{ XPS } & & \\
\hline & $\begin{array}{l}\text { (110) Peak } \\
\left(^{\circ}\right)\end{array}$ & $\begin{array}{l}\text { Particle size } \\
\quad(\mathrm{nm})\end{array}$ & & Ru metal & $\begin{array}{c}\text { Ru oxide } \\
\left(\mathrm{RuO}_{2}\right)\end{array}$ & $\mathrm{Se}$ & $\begin{array}{l}\text { Se oxide } \\
\left(\mathrm{SeO}_{2}\right)\end{array}$ & $\begin{array}{l}\text { Current density } \\
\text { at } 0.7 \mathrm{~V}\left(\mathrm{~mA} \mathrm{~cm}^{-2}\right)\end{array}$ & $\begin{array}{c}\text { Mass activity } \\
\left(\mathrm{mA} \mathrm{g}_{\mathrm{Ru}}^{-1}\right)\end{array}$ \\
\hline $\mathrm{Ru} / \mathrm{C}$ & 69.40 & 4.9 & - & $38.0 \%$ & $62.0 \%$ & - & - & -1.26 & -1102.50 \\
\hline $\mathrm{Ru}_{95} \mathrm{Se}_{5} / \mathrm{C}$ & 69.40 & 5.1 & $95.1: 4.9$ & $41.0 \%$ & $59.0 \%$ & $62.5 \%$ & $37.5 \%$ & -1.47 & -1353.95 \\
\hline $\mathrm{Ru}_{90} \mathrm{Se}_{10} / \mathrm{C}$ & 69.42 & 3.9 & $89.5: 10.5$ & $50.7 \%$ & $49.3 \%$ & $63.0 \%$ & $37.0 \%$ & -1.55 & -1506.94 \\
\hline $\mathrm{Ru}_{85} \mathrm{Se}_{15} / \mathrm{C}$ & 69.45 & 3.6 & $84.0: 16.0$ & $56.4 \%$ & $43.6 \%$ & $61.4 \%$ & $38.6 \%$ & -1.74 & -1797.17 \\
\hline $\mathrm{Ru}_{80} \mathrm{Se}_{20} / \mathrm{C}$ & 69.50 & 4.1 & $82.1: 17.9$ & $60.6 \%$ & $39.4 \%$ & $61.0 \%$ & $39.0 \%$ & -1.87 & -2045.31 \\
\hline $\mathrm{Ru}_{75} \mathrm{Se}_{25} / \mathrm{C}$ & 69.50 & 4.6 & $76.6: 23.4$ & $57.0 \%$ & $43.0 \%$ & $63.1 \%$ & $36.9 \%$ & -0.95 & -1108.33 \\
\hline
\end{tabular}

(a)

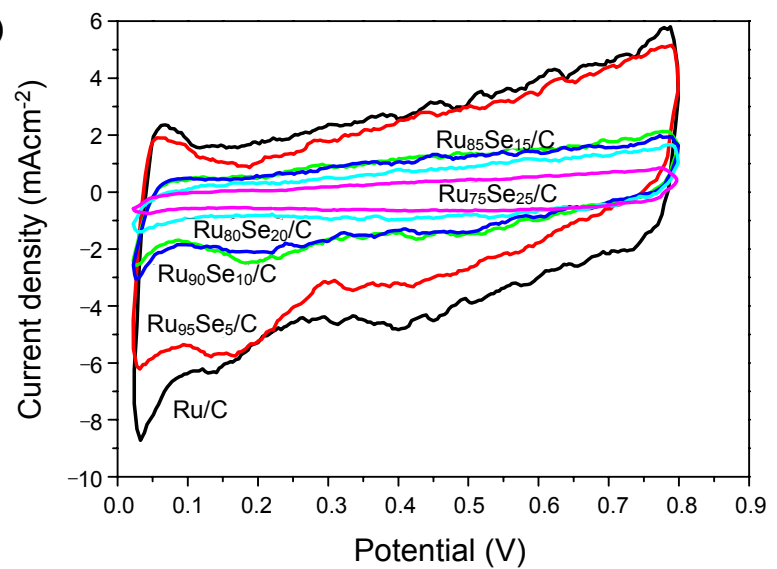

(c)

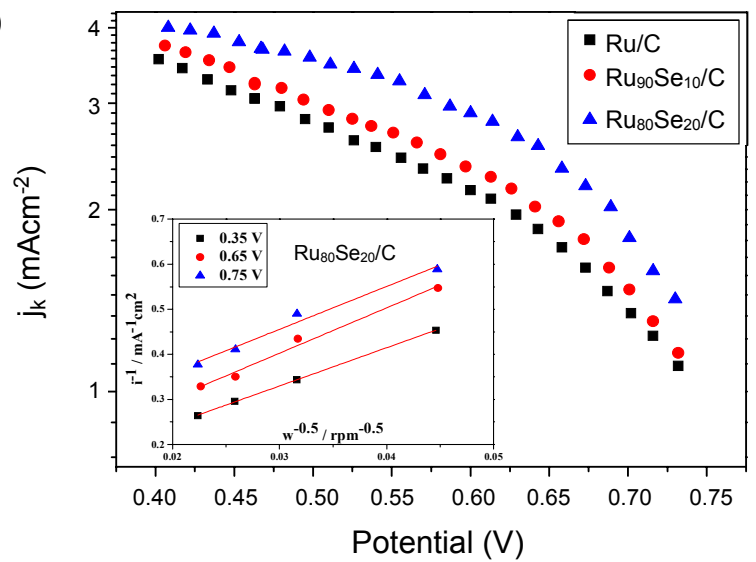

(b)

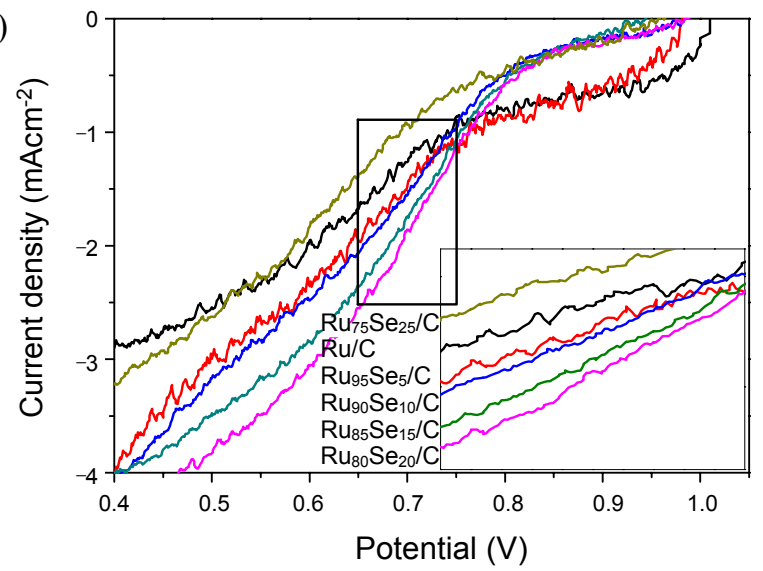

(d)

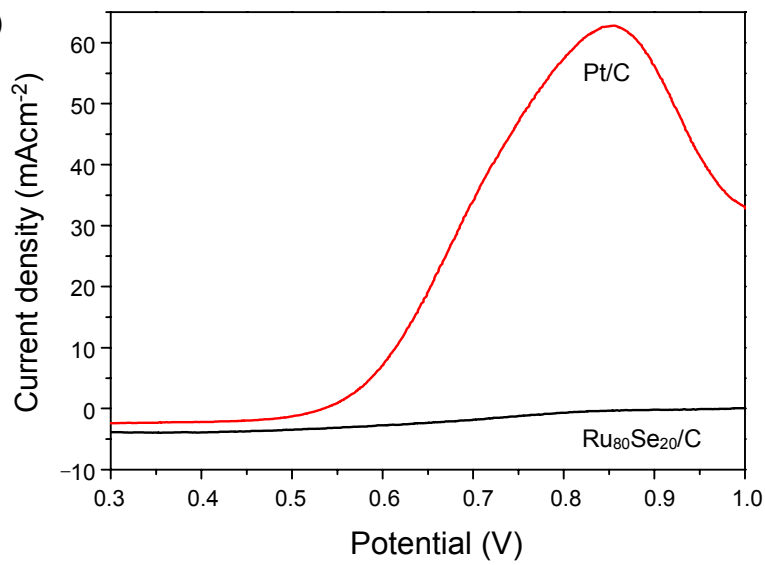

Figure 2. Electrochemical characterization; Cyclic voltammetry results (a) and ORR results (b) for the Ru/C, $\mathrm{Ru}_{95} \mathrm{Se}_{5} / \mathrm{C}, \mathrm{Ru}_{90} \mathrm{Se}_{10} / \mathrm{C}, \mathrm{Ru}_{85} \mathrm{Se}_{15} / \mathrm{C}$, $\mathrm{Ru}_{80} \mathrm{Se}_{20} / \mathrm{C}$, and $\mathrm{Ru}_{75} \mathrm{Se}_{25} / \mathrm{C}$ catalysts. Tafel plots for the $\mathrm{ORR}$ of $\mathrm{Ru} / \mathrm{C}, \mathrm{Ru}_{90} \mathrm{Se}_{10} / \mathrm{C}$, and $\mathrm{Ru}_{80} \mathrm{Se}_{20} / \mathrm{C}$ catalysts (c). Methanol tolerance results for the $\mathrm{Ru}_{80} \mathrm{Se}_{20} / \mathrm{C}$ catalyst (d).

est ORR activity which was $84 \%$ of the activity of the $\mathrm{Pt} / \mathrm{C}$. Activity of the $\mathrm{Ru}_{80} \mathrm{Se}_{20} / \mathrm{C}$ catalyst was higher by $33 \%$ than that of the $\mathrm{Ru} / \mathrm{C}$. The mass activities were calculated from the current densities. The mass activity of the $\mathrm{Ru}_{80} \mathrm{Se}_{20} / \mathrm{C}(-2045.31$ $\mathrm{mA} \mathrm{g}_{\mathrm{Ru}}^{-1}$ ) showed also the highest activity in the RuSe catalysts. The mass activity of $\mathrm{Ru}_{80} \mathrm{Se}_{20} / \mathrm{C}$ was almost twice as large as that of the $\mathrm{Ru} / \mathrm{C}$. The above observations, optimum concentration of RuSe composition was the $\mathrm{Ru}_{80} \mathrm{Se}_{20} / \mathrm{C}$ which is similar with a previous study. Bron et al. suggested $\mathrm{Ru}_{85} \mathrm{Se}_{15}$ composition as the optimum concentration. ${ }^{48}$ This difference is caused by difference surface features such as amounts of Ru metal and $\mathrm{Ru}$ oxide originated from synthesis process. Se modified $\mathrm{Ru}$ catalysts showed the improved ORR activity which has been related to chemical stabilization of metallic Ru surface against oxidation. ${ }^{49}$ Babu et al. reported that $\mathrm{Se}$ on the $\mathrm{Ru}$ surface existed as metallic form due to charge transfer from Ru to Se. ${ }^{50}$ This charge transfer prevents the oxidation of Ru surface. In Fig. 2(c), the kinetic currents are calculated using the KouteckyLevich (K-L) equation and Tafel plots. The RDE data are analyzed using the K-L equation: 


$$
\frac{1}{j}=\frac{1}{j_{k}}+\frac{1}{j_{D}}=\frac{1}{j_{k}}+\frac{1}{B \omega^{1 / 2}}
$$

Where $\mathrm{j}$ is the measured current density, $\mathrm{j}_{\mathrm{k}}$ is the kinetic current density, $\mathrm{j}_{\mathrm{D}}$ is the diffusion-limited current density, $\omega$ is the rotation rate of the electrode and B is the Levich constant. The value of the B can be obtained from the slope of the K-L plot. The calculated kinetic currents $\mathrm{j}_{\mathrm{k}}$ of $\mathrm{Ru} / \mathrm{C}, \mathrm{Ru}_{90} \mathrm{Se}_{10} / \mathrm{C}$ and $\mathrm{Ru}_{80} \mathrm{Se}_{20} / \mathrm{C}$ are displayed in semi-logarithmic plots versus the potential $\mathrm{E}$. The corrected $\mathrm{j}_{\mathrm{k}}$ of three catalysts are compared at $0.7 \mathrm{~V}$. The kinetic current densities at $0.7 \mathrm{~V}$ were $1.34,1.47$ and $1.80 \mathrm{~mA} \mathrm{~cm}^{-2}$ for the $\mathrm{Ru} / \mathrm{C}, \mathrm{Ru}_{90} \mathrm{Se}_{10} / \mathrm{C}$ and $\mathrm{Ru}_{80} \mathrm{Se}_{20} / \mathrm{C}$.

The $\mathrm{Ru}_{80} \mathrm{Se}_{20} / \mathrm{C}$ catalyst showed the highest kinetic activity. As shown in the Tafel plot, Se modification of the Ru surface leads to increasing the catalytic activity of the Ru catalyst. The $\mathrm{Ru}_{80} \mathrm{Se}_{20} / \mathrm{C}$ catalyst showed significantly high methanol tolerant property compared to the $\mathrm{Pt} / \mathrm{C}$ (Fig. 2(d)). The current density under methanol environment of $\mathrm{Ru}_{80} \mathrm{Se}_{20} / \mathrm{C}$ catalyst was $-1.82 \mathrm{~mA} \mathrm{~cm}^{-2}$, which is $97.3 \%$ performance of the activity without methanol. It is the reason that $\mathrm{Ru}$ catalyst has almost no methanol oxidation property. The high methanol property make $\mathrm{Ru}_{80} \mathrm{Se}_{20} / \mathrm{C}$ a powerful candidate as a cathode material of DMFCs. A summary of the electrochemical analysis results is tabulated in Table 1.

Fig. 3 exhibits the XPS results of Ru $3 \mathrm{~d}$ core level for $\mathrm{Ru}_{95} \mathrm{Se}_{5} / \mathrm{C}$ (Fig. 3 (a)) and $\mathrm{Ru}_{80} \mathrm{Se}_{20} / \mathrm{C}$ (Fig. 3(b)). The results of all catalysts for $\mathrm{Ru} 3 \mathrm{~d}$ core level are summarized in Table 1. The prepared catalysts were supported by Vulcan XC72R carbon material which shows the large $\mathrm{C} 1 \mathrm{~s}$ peak in $284.5 \mathrm{eV}$. The metallic $\mathrm{Ru}$ doublet with $3 \mathrm{~d}_{5 / 2}$ and $3 \mathrm{~d}_{3 / 2}$ components shows peaks at 280.1 $\mathrm{eV}$ and $284.3 \mathrm{eV}$, respectively. ${ }^{51}$ From peak deconvolution, the $\mathrm{Ru}$ surface was composed of a metallic Ru and an oxide form. The $\mathrm{RuO}_{2}$ doublet with $3 \mathrm{~d}_{5 / 2}$ and $3 \mathrm{~d}_{3 / 2}$ components exhibit peaks at $281.3 \mathrm{eV}$ and $285.5 \mathrm{eV}$, respectively. ${ }^{52,53}$ The ratios of the metallic Ru to $\mathrm{RuO}_{2}$ were calculated from the area of the $3 \mathrm{~d}_{5 / 2}$ peaks. The $\mathrm{Ru} / \mathrm{C}$ catalyst was composed of $38 \%$ metallic $\mathrm{Ru}$ and $62 \% \mathrm{RuO}_{2}$. With increased Se amounts, amounts of metallic $\mathrm{Ru}$ on the catalysts surfaces were increased up to $60.6 \%$ on the $\mathrm{Ru}_{80} \mathrm{Se}_{20} / \mathrm{C}$ surface. In the case of $\mathrm{Ru}_{75} \mathrm{Se}_{25} / \mathrm{C}$ catalysts, similar surface composition with $\mathrm{Ru}_{80} \mathrm{Se}_{20} / \mathrm{C}$ was observed. It has good agreement with previous study. As mentioned above, Se modification on Ru surface makes Ru surface metallic. Lewera et al. suggested that the oxygen in the Ru surface is strongly bonded to $\mathrm{Ru}$, and Se is weakening the Ru-O bond. ${ }^{54}$ In Fig. 3(c), the XPS result of Se $3 \mathrm{~d}$ core level for $\mathrm{Ru}_{80} \mathrm{Se}_{20} / \mathrm{C}$ is exhibited. The results of all catalysts for Se $3 \mathrm{~d}$ core level are summarized in Table 1 . The binding energy peak for $\mathrm{Se} 3 \mathrm{~d}_{3 / 2}$ peak appear at $55.2 \mathrm{eV}$. The Se $3 \mathrm{~d}_{3 / 2}$ peak for oxidized form appears at about $58.5-59.0 \mathrm{eV}{ }^{52,53} \mathrm{The}^{\mathrm{Ru}} \mathrm{u}_{80} \mathrm{Se}_{20} / \mathrm{C}$ catalyst was composed of $61.0 \%$ elemental Se and $39.0 \%$ oxidized Se. Other catalysts show similar results to $\mathrm{Ru}_{80} \mathrm{Se}_{20} / \mathrm{C}$. All catalysts appeared the large amount of oxidized Se. In a previous study, Zhu et al. reported that elemental Se powder were synthesized by polyol method in similar conditions. ${ }^{55}$ It means that reduction of the Se was affected by the Ru species. The oxidized Se on the RuSe catalysts should be affected by the charge transfer from Ru to Se on Se modified Ru surface. (a)

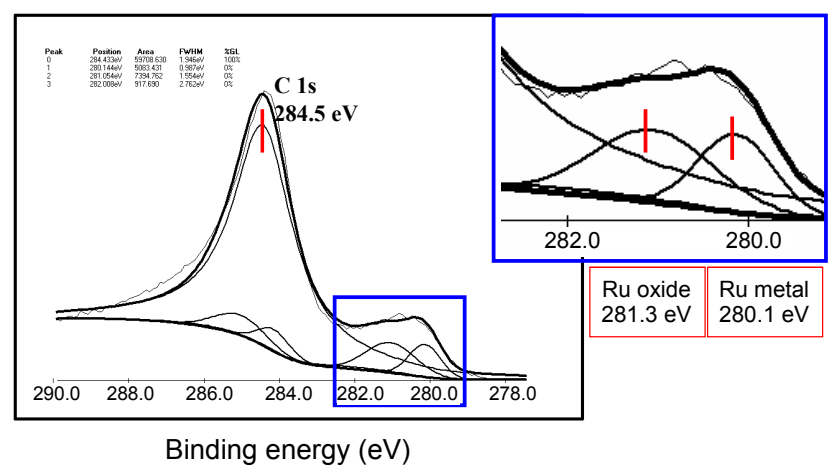

(b)

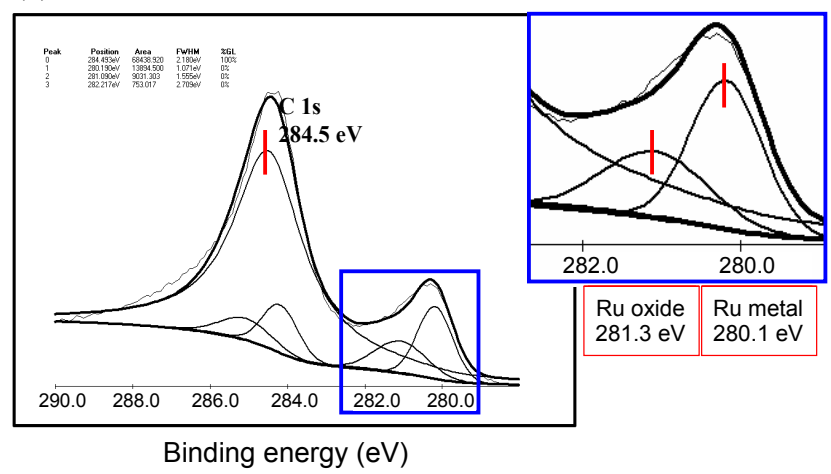

(c)

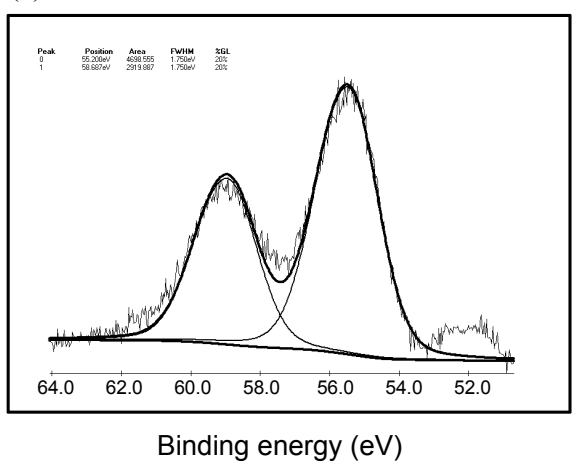

Figure 3. The XPS spectra of the $\mathrm{Ru}_{95} \mathrm{Se}_{5} / \mathrm{C}$ and $\mathrm{Ru}_{80} \mathrm{Se}_{20} / \mathrm{C}$ : Ru 3d regions for the $\mathrm{Ru}_{95} \mathrm{Se}_{5} / \mathrm{C}$ (a) and the $\mathrm{Ru}_{80} \mathrm{Se}_{20} / \mathrm{C}$ (b) catalysts and Se $3 \mathrm{~d}$ region for the $\mathrm{Ru}_{80} \mathrm{Se}_{20} / \mathrm{C}$ (c).

Fig. 4 shows the single cell performance of $\mathrm{Ru}_{80} \mathrm{Se}_{20} / \mathrm{C}$ catalyst. The commercial $\mathrm{Pt} / \mathrm{C}$ was prepared for comparison. MEA1 was composed of $\mathrm{PtRu} / \mathrm{C}$ (anode) and $\mathrm{Pt} / \mathrm{C}$ (cathode) and MEA2 was composed of $\mathrm{PtRu} / \mathrm{C}$ (anode) and $\mathrm{Ru}_{80} \mathrm{Se}_{20} / \mathrm{C}$ (cathode). The open circuit voltages (OCV) of MEA1 and MEA2 were $0.62 \mathrm{~V}$ and $0.70 \mathrm{~V}$, respectively. The MEA2 showed improved OCV due to outstanding methanol tolerant property of $\mathrm{Ru}_{80} \mathrm{Se}_{20} / \mathrm{C}$ which is exhibited in electrochemical study. As expected, MEA1 showed much higher max power density, $73.5 \mathrm{~mW} \mathrm{~cm}^{-2}$ than MEA2. Max power density of MEA2 was $39.5 \mathrm{~mW} \mathrm{~cm}^{-2}$. The $\mathrm{Ru}_{80} \mathrm{Se}_{20} / \mathrm{C}$ which is non-Pt cathode material showed $53.6 \%$ max power density and the improved OCV when comparing with $\mathrm{Pt} / \mathrm{C}$. This is suitable for cathode material to substitute $\mathrm{Pt}$ but the improved ORR activity of RuSe catalysts is essential. 


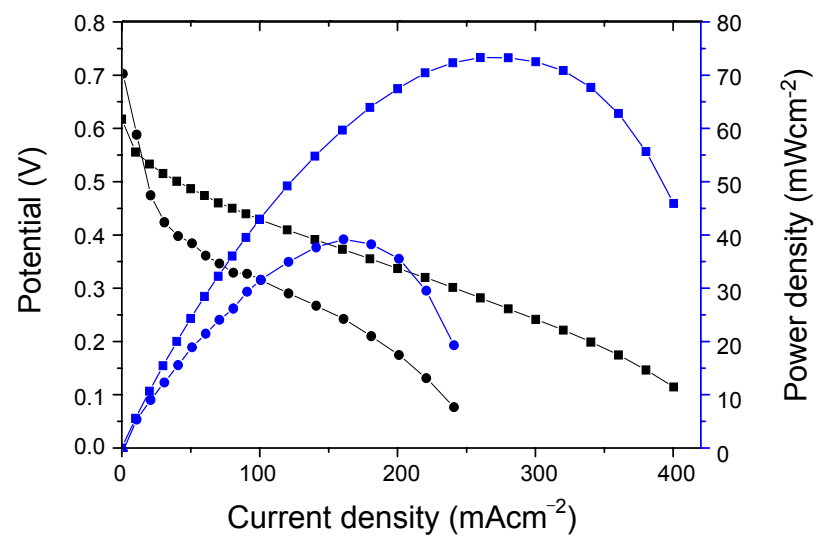

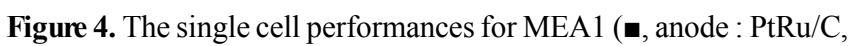
cathode : $\mathrm{Pt} / \mathrm{C})$ and MEA2 $\left(\bullet\right.$, anode $: \mathrm{PtRu} / \mathrm{C}$, cathode $\left.: \mathrm{Ru}_{80} \mathrm{Se}_{20} / \mathrm{C}\right)$ in DMFC.

\section{Conclusions}

The Se modified Ru catalysts were synthesized via a polyol method. By adding Se component, amounts of metallic Ru surface were increased and improvement of ORR activity was achieved. Optimum concentration of RuSe composition was the $\mathrm{Ru}_{80} \mathrm{Se}_{20} / \mathrm{C}$ which is almost twice as higher than $\mathrm{Ru} / \mathrm{C}$ in mass activity. Furthermore, the $\mathrm{Ru}_{80} \mathrm{Se}_{20} / \mathrm{C}$ showed prominent methanol tolerant property. Electrochemical characterization and single cell measurement showed that the $\mathrm{Ru}_{80} \mathrm{Se}_{20} / \mathrm{C}$ is suitable for cathode material of DMFCs.

Acknowledgments. This work was supported by the Korea Science \& Engineering Foundation (KOSEF) grant (WCU program, 31-2008-000-10055-0) funded by the Ministry of Education and Science \& Technology (MEST) and the National Research Foundation of Korea(NRF) grant funded by the MEST (No. 2009-0092783).

\section{References}

1. Jeon, M. K.; Lee, K. R.; Oh, K. S.; Hong, D. S.; Won, J. Y.; Li, S.; Woo, S. I. J. Power Sources 2006, 158, 1344.

2. Choi, W. C.; Kim, J. D.; Woo, S. I. Catal. Today 2002, 74, 235.

3. Jeon, M. K.; Won, J. Y.; Woo, S. I. Electrochem. Solid-State Lett. 2007, 10, B25.

4. Choi, W. C.; Kim, J. D.; Woo, S. I. J. Power Sources 2001, 96, 411.

5. Antolini, E. Appl. Catal. B: Environ. 2007, 74, 337.

6. Lee, K. R.; Jeon, M. K.; Woo, S. I. Appl. Catal. B-Environ. 2009, 91, 428.

7. Jeon, M. K.; Lee, K. R.; Jeon, H. J.; Woo, S. I. J. Appl. Electrochem. 2009, 39, 1503.

8. Travitsky, N.; Ripenbein, T.; Golodnitsky, D.; Rosenberg, Y.; Burshtein, L.; Pele, E. J. Power Sources 2006, 161, 782.

9. Whitacre, J. F.; Valdez, T. I.; Narayanan, S. R. Electorchim. Acta 2008, 53, 3680 .

10. Jeon, M. K.; Zhang, Y.; McGinn, P. J. Electrochim. Acta 2010, 55,5318

11. Schulenburg, H.; Mller, E.; Khelashvili, G.; Roser, T.; Bnnemann, H.; Wokaun, A.; Scherer, G. G. J. Phys. Chem. C 2009, 113, 4069.

12. Antolini, E.; Salgado, J. R. C.; Santos, L. G. R. A.; Garcia, G.; Ticianelli, E. A.; Pastor, E.; Gonzalez, E. R. J. Appl. Electrochem. 2006, 36, 355 .
13. Jeon, M. K.; Liu, J. H.; Lee, K. R.; Lee, J. W.; McGinn, P. J.; Woo, S. I. Fuel Cells 2010, 10, 93.

14. Liu, J. H.; Jeon, M. K.; Woo, S. I. Appl. Surf. Sci. 2006, 252, 2580.

15. Choi, W. C.; Woo, S. I.; Jeon, M. K.; Sohn, J. M.; Kim, M. R.; Jeon, H. J. Adv. Mater. 2005, 17, 446.

16. Jeon, M. K.; Lee, K. R.; Lee, W. S.; Daimon, H.; Nakahara, A.; Woo, S. I. J. Power Sources 2008, 185, 927.

17. Gupta, G.; Slanac, D. A.; Kumar, P.; Camacho, J. D. W.; Kim, J.; Ryoo, R.; Stevenson, K. J.; Johnston, K. P. J. Phys. Chem. C 2010, 114, 10796.

18. Gasteiger, H. A.; Kocha, S. S.; Sompalli, B.; Wagner, F. T. Appl. Catal. B 2005, 56, 9 .

19. Srivastava, R.; Mani, P.; Hahn, N.; Strasser, P. Angew. Chem. Int. Ed. 2007, 46, 8988.

20. Antolini, E.; Lopes, T.; Gonzalez, E. R. J. Alloys. Comp. 2008, 461, 253.

21. DeLuca, N. W.; Elabd, Y. A. J. Polym. Sci. Polym. Phys. 2006, 44, 2201.

22. Suo, Y.; Zhuang, L.; Lu, J. Angew. Chem. Int. Ed. 2007, 46, 2862.

23. Shao, M. H.; Sasaki, K.; Adzic, R. R. J. Am. Chem. Soc. 2006, 128, 3526.

24. Sarker, A.; Murugan, A. V.; Manthiram, A. J. Phys. Chem. C 2008, $112,12037$.

25. Widelov, A.; Larsson, R. Electrochim. Acta 1992, 37, 187.

26. Bashyam, R.; Zelenay, P. Nature 2006, 443, 63.

27. Babu, P. K.; Lewera, A.; Chung, J. H.; Hunger, R.; Jaegermann, W.; Vante, N. A.; Wiechowski, A.; Oldfield, E. J. Am. Chem. Soc. 2007, 129, 15140.

28. Lee, J. W.; Popov, B. N. J. Solid State Electrochem. 2007, 11, 1355.

29. Lee, K. R.; Lee, K. U.; Lee, J. W.; Ahn, B. T.; Woo, S. I. Electrochem. Commun. 2010, in press.

30. Liu, G. C.; Dahn, J. R. Appl. Catal. A: General 2008, 347, 43.

31. Matter, P. H.; Zhang, L.; Ozkan, U. S. J. Catal. 2006, $239,83$.

32. Vante, N. A.; Jaegermann, W.; Tributsch, H.; Honle, W.; Yvon, K. J. Am. Chem. Soc. 1897, 109, 3251.

33. Vante, N. A.; Tributsch, H.; Feria, O. S. Electrochim. Acta 1995, $40,567$.

34. Fievet, F.; Lagier, J. P.; Blin, L. B.; Beaudoin, B.; Figlarz, M. Solid State Ionics 1989, 32/33, 198.

35. Yan, S.; Sun, G.; Tian, J.; Jiang, L.; Qi, J.; Xin, Q. Eletrochim. Acta 2006, 52, 1692.

36. Schmidt, T. J.; Gasteiger, H. A.; Stäb, G. D.; Urban, P. M.; Kolb, D. M.; Behm, R. J. J. Electrochem. Soc. 1998, 145, 2354.

37. Li, W.; Zhou, W.; Li, H.; Zhou, Z.; Zhou, B.; Sun, G.; Xin, Q. Electrochim Acta 2004, 49, 1045.

38. Serov, A. A.; Min, M.; Chai, G.; Han, S.; Kang, S.; Kwak, C. J. Power Sources 2008, 175, 175.

39. He, C. Z.; Kunz, H. R.; Fenton, J. M. J. Electrochem. Soc. 1997, 144,970

40. Cao, D.; Wiechowski, A.; Inukai, J.; Vante, N. A. J. Electrochemical Soc. 2006, 153(5), A869.

41. Nagabhushana, K. S.; Dinjus, E.; Bőnnemann, H.; Zaikovskii, V.; Hartnig, C.; Zehl, G.; Dorbandt, I.; Fiechter, S.; Bogdanoff, P. J. Appl. Electrochem. 2007, 37, 1515.

42. Jordanov, S. H.; Kozlowaka, H. A.; Vukovic, M.; Conway, B. E. J. Phys. Chem. 1977, 81, 2271.

43. Colmenares, L.; Jusys, Z.; Behm, R. J. J. Phys. Chem. C 2007, 111, 1273.

44. Michell, D.; Rand, D. A. J.; Woods, R. J. Electroanal. Chem. Interfacial Electrochem. 1978, 89, 11.

45. Kinoshita, K.; Ross, P. N. J. Electroanal. Chem. Interfacial Electrochem. 1977, 78, 313.

46. Pinheiro, A. L. N.; Zei, M. S.; Ertl, G. Phys. Chem. Chem. Phys. 2005, 7, 1300

47. Dassenoy, F.; Vogel, W.; Vante, N. A. J. Phys. Chem. B 2002, 106, 12152.

48. Bron, M.; Bogdanoff, P.; Fiechter, S.; Dorbandt, I.; Hilgendorff, 
M.; Schulenburg, G.; Tributsch, H. J. Electroanal. Chem. 2001, 500,510 .

49. Colmenares, L.; Jusys, Z.; Behm, R. J. Langmuir 2006, $22,10437$.

50. Babu, P. K.; Lewera, A.; Chung, J. H.; Hunger, R.; Jaegermann, W.; Vante, N. A.; Wiechowski, A.; Oldfield, E. J. Am. Chem. Soc. 2007, 129, 15140 .

51. Wagner, C. D.; Naumkin, A. V.; Vass, A. K.; Allison, J. W.; Powell, C. J.; Rumble, J. R., Jr. NIST standard Reference Database
20, Version 3.4.

52. Vericat, C.; Wakisaka, M.; Haasch, R.; Bagus, P. S.; Wiechowski, A. J. Solid State Electorhcem. 2004, 8, 794.

53. Rochefort, D.; Dabo, P.; Guay, D.; Sherwood, P. M. A. Electrochim. Acta 2003, 48, 4245.

54. Lewera, A.; Inukai, J.; Zhou, W. P.; Cao, K.; Duong, H. T.; Vante, N. A.; Wiechowski, A. Electrochimica Acta 2007, 52, 5759. 55. Zhu, Y. J.; Hu, X. L. Mater. Lett. 2004, 58, 1234. 